\section{Prevalence of anxiety in patients admitted to a university hospital in southern Brazil and associated factors}

\section{Prevalência de ansiedade em \\ pacientes internados num hospital universitário do sul do Brasil e fatores associados}

Inês Gullich'

Andrews Barcellos Ramos'

Tiago Rafael Anschau Zan'

Cíntia Scherer'

Raúl Andrés Mendoza-Sassi'

'Universidade Federal do Rio Grande - Rio Grande (RS), Brazil.

\section{Abstract}

Objective: To identify the prevalence of anxiety in adults hospitalized in the clinical ward of a university hospital and to analyze the possible associated factors. Method: A cross-sectional study was performed in a university hospital. All interviewees answered a specific questionnaire and the Hospital Anxiety and Depression Scale. A Poisson regression was used to calculate prevalence ratios with $95 \%$ confidence intervals. Results: 282 patients were enrolled. The prevalence of anxiety was $33.7 \%$ (95\% CI 28.2 - 39.3). Characteristics associated with the outcome were female gender (RP 2.44), age $\geq 60$ years (PR 0.65), consultation in primary health care (PR 2.37), estimated time of contact between patient and student $>30 \mathrm{~min}$ (RP 1.36), high blood pressure ( $\mathrm{PR}$ 1.57), diabetes mellitus (PR 1.43), and obesity (RP 1.43). Conclusion: This study found prevalence of high anxiety. It may be associated with certain characteristics of the patients (gender, age, chronic diseases); the medical appointment in primary care and time (estimated by the patient) that the student remained with this patient. The need for a focused approach to mental health care within the hospital has been discussed for a long time. The particularity of this study refers to the environment of a university hospital and to what extent the environment and the patient's relationship with the student are associated with higher prevalence of anxiety.

Keywords: Anxiety. Prevalence. University Hospitals. Hospital care. Hospitalization. Inpatients. 


\section{Resumo}

Objetivo: Identificar a prevalência de ansiedade em adultos hospitalizados na enfermaria de clínica médica de um hospital universitário e analisar seus possíveis fatores associados. Método: Estudo transversal realizado em hospital universitário, mediante a aplicação de instrumento específico e a Hospital Anxiety and Depression Scale. Foi realizada a regressão de Poisson para o cálculo das Razões de Prevalência com Intervalos de Confiança 95\%. Resultados: Participaram 282 pacientes. A prevalência de ansiedade encontrada foi de 33,7\% (IC95\% 28,2 - 39,3). Mostraram-se associadas à ansiedade o gênero feminino (RP 2,44), a idade $\geq 60$ anos (RP $0,65)$, consulta habitual na atenção primária ( $\mathrm{RP} 2,37$ ), estimativa do paciente sobre o tempo que o aluno permaneceu com ele $>30$ min (RP 1,36), a hipertensão arterial sistêmica (RP 1,57), a diabetes mellitus (RP 1,43) e a obesidade (RP 1,43). Conclusão: $\mathrm{O}$ presente estudo encontrou uma prevalência de ansiedade elevada. Essa pode estar associada a algumas características do paciente (gênero, idade, doenças crônicas), à consulta habitual em atenção primária e ao tempo (estimado pelo paciente) que o aluno permaneceu com esse enfermo. A necessidade de uma abordagem voltada à saúde mental no âmbito do atendimento hospitalar já vem sendo discutida há muito tempo. A particularidade do presente estudo refere-se ao ambiente de um hospital universitário e em que medida este ambiente e a relação do paciente com o aluno associam-se a uma maior prevalência de ansiedade.

Palavras-chave: Ansiedade. Prevalência. Hospitais Universitários. Assistência hospitalar. Hospitalização. Pacientes Internados.

\section{Introduction}

Anxiety is a universal experience that appears in response to demands or threats as a sign of search for adaptation ${ }^{1}$. It can be considered pathological when representing a response that does not properly correspond to a stimulus, in a way that the individual experiments insecurity, goes through apprehensive anticipation, finds difficulties to adjust to the environment and presents signals of suffering ${ }^{2}$. The hospital scope increases the possibility to trigger the anxiety among patients ${ }^{3}$, which disturbs and limits the patient in terms of facing his or her condition; as to the doctor, it may make diagnosis and treatment more difficult ${ }^{4}$. The exposure of intimacy to strangers, the contact with other people with situations of illness and the uncertainty toward the evolution of the treatment can also become highly anxiogenic ${ }^{5}$. In these cases, usually the occurrence of inexplicable physical symptoms increases, and the time of hospitalization prolongs significantly ${ }^{6}$.

Prevalence surveys show that 20 to $60 \%$ of inpatients in general hospitals suffer from some sort of psychiatric disorder, and depressive and anxiety disorders are amongst the most common ones. The variation of these ciphers depends on the studied population and methodological definitions ${ }^{7}$. Depending on the unit where the patient is located, or on the comorbidities that he or she presents, there are different levels of anxiety. The high prevalence (around $65 \%$ ) was related to patients in preoperative or those with chronic pain ${ }^{8,9}$. Other situations, like the fact of being unemployed, are related to higher levels of anxiety during hospitalization ${ }^{8}$. The female gender proved to be associated with higher levels of anxiety during hospitalization in relation to the opposite gender ${ }^{10}$.

Despite causing considerable pain and clinical implications, it is estimated that only $35 \%$ of them receive specialized care in mental health. Besides, many symptoms can be a result both of the organic and the mental pathology, leading to confusion in the diagnosis ${ }^{7}$. 
Concerning the variables associated with anxiety in hospitalized patients, the found studies prioritized the matter of sociodemographic aspects and comorbidities. Other factors that may be associated have not been explored yet. For instance, there is lack of studies clarifying the variables associated with anxiety in patients hospitalized in a university hospital with their particular characteristics, such as the presence and time of permanence of students, as well as variables related to habits, costumes, and chronic comorbidities, among others. Therefore, this study aimed at identifying the prevalence of anxiety in adults admitted to the clinical ward of a university hospital and at analyzing its possible associated factors, thus contributing for the full care for the inpatient.

\section{Methodology}

\section{Design and location}

It was a cross-sectional study conducted with the patients in the clinical ward of university hospital Dr. Miguel Riet Corrêa Júnior. This public school hospital is part of Universidade Federal do Rio Grande (FURG), located in the city of Rio Grande, state of Rio Grande do Sul.

\section{Participants}

Participants were the inpatients of the referred hospital located in the clinical ward from September 2010 to January 2011. The sample was composed of patients aged more than 18 years old, of both genders, with minimum admission time of 48 hours. Exclusion criteria included patients with difficulties to answer the questionnaire properly, such as the ones with hearing, speech or mental impairment. In order to calculate the prevalence sample, a $95 \%$ confidence level was used, as well as estimates of prevalence of anxiety of $40 \%( \pm 6 \%)$, accounting for 282 patients, with the addition of $10 \%$ of loss prediction.

\section{Instruments}

The used instrument was a pre-codified questionnaire with the following independente variables: a) sociodemographic (age, gender, self-declared skin color, marital status, income, work situation, schooling, religion); b) habits and costumes (alcohol consumption, smoking, physical activity); c) health behavior (if the person frequently sees a doctor when feeling sick, where they go to, since when do they see this doctor); d) hospitalization and medical history data collected from medical records - (time of hospitalization, previous admission in the past year, classes and number of prescribed medicines, typology and number of chronic diseases); e) assessment of the patient with regard to the presence and time of stay of students. These variables were assessed by means of a dichotomous question (In this hospitalization period, has any nursing/ medical student come to examine/talk to you?) and an open question (In average, how long has the student stayed with you in each opportunity?).

In order to check the habit of alcohol consomuption, the $\mathrm{CAGE}^{11}$ and AUDIT ${ }^{12}$ questionnaires were used. Both are validated in Brazil and do not require authorized training to be used. CAGE has four questions and the cutoff point is considered as two affirmative answers, suggesting positive screening for alcohol abuse or dependence $^{13}$. AUDIT is comprised of ten questions, and the score reached by the individual after answering the items enables the classification as to the use of the substance as follows: Zone I (low risk): 0 to 7 points; Zone II (use of risk): 8 to 15 points; Zone III (harmful use): 16 to 19 points; Zone IV (probable dependence): 20 to 40 points $^{14}$. To analyze the habit of smoking, besides the direct question (do you smoke?I, the Fagerström test for nicotine dependence was also used. It is a worldwide validated and used test that functions as an assessment tool consisting of a questionnaire with six questions. It is possible to reach the maximum score of 10 
points. More than six points indicate that, most likely, the patient presents high risk of nicotine dependence ${ }^{15}$.

For the anxiety closure, the Hospital Anxiety and Depression Scale (HADS) was used. Its version in Portuguese has been tested and validated among inpatients ${ }^{7}$. In the construction of HADS, the vegetative symptoms that may occur in physical conditions were prevented; therefore, it is especially useful to assess mood disorders in situations of hospitalization. The HAD scale contains 14 multiple-choice questions and consists of two sub-scales: anxiety and depression, with seven items each. The global score for each sub-scale ranges from 0 to 21 points. In this study, the anxiety sub-scale was assessed, and the considered cutoff point was $\geq 9$ points ${ }^{16}$.

After the conduction of the pilot study, the instrument was applied by three medical students attending the tenth semester. Interviewers followed-up the hospitalizations and hospital discharges daily, thus avoiding losses.

\section{Data analysis}

For purposes of quality control, $10 \%$ of the interviewees were revisited. Some of the questions from the original instrument were applied again in order to study test-retest reliability, and for such end the Kappa index was calculated.

The codified data were inserted in Epinfo 6.04d, by two independent typists, and afterward the data cleansing process took place, considering errors of amplitude and consistency.

Statistical analysis was processed in three phases. In the descriptive phase, central and dispersion measurements were calculated for numerical variables and, in case of categorical variables, the respective proportions were calculated. For the outcome, the prevalence and the $95 \%$ confidence interval $(95 \% \mathrm{CI})$ were calculated. In the second phase, the association between the studied factors and the outcome was analyzed with the chi-square test (or Fisher's exact test) for categorical variables, and Student's t-test was used for continuous variables. In the third phase, in order to explore the independent effect of variables, the choice was to use the Poisson regression with large confidence intervals. This type of regression enables to calculate prevalence ratios, and it is also adequate to measure the association between factors and outcome in crosssectional studies. The variables inserted in the model should have obtained $\mathrm{p} \leq 0.2$ in the bivariate analysis, except for the sociodemographic variables that were included regardless of value. The regression was performed with the use of a hierarchic analysis model in four levels ${ }^{17}$. Variables in each level were included in blocks, and their permanence inside the model was conditioned to $\mathrm{p} \leq 0.2$. The variables of each level that met this criterion were adjusted with the following level until completing all the four levels (Figure 1). Prevalence Ratios (PR) and $95 \% \mathrm{CI}$ were calculated for the different factors analyzed with regard to the outcome. The regression was "backwards". PR and 95\%CI were estimated for each level, and statistical significance was assessed with the Walt test. When variables were ordinal, with three or more categories, and also when a linear trend was observed, the choice was to use the Wald test for linear trend. In the case of ordinal variables with no linear trend, the heterogeneity test was used. In all of the analyses, the cutoff point was bicaudal $\mathrm{p}<0.05$.

\section{Ethical aspects}

This study was approved by the Research Ethics Committe in the Health Field of Universidade Federal do Rio Grande (report n. 78/2010). Before answering the questionnaires, participants were asked to sign the informed consent form. The doctors in charge were warned about the interviewers about the patients who presented with positive tests for the outcome. The authors declared there were no conflicts of interest.

\section{Results}

At the end of the study, 284 patients were selected; there were two refusals 


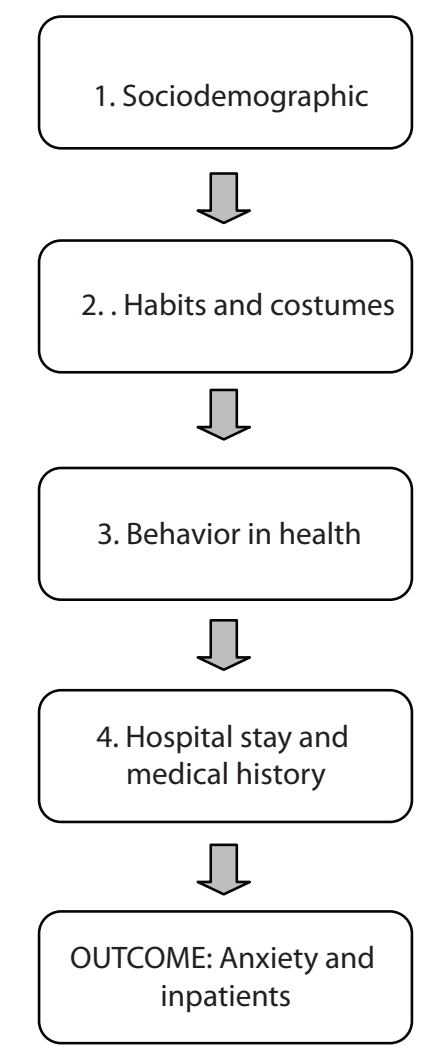

Figure 1 - Hierarquical model analysis.

Figura 1 - Modelo de análise hierárquica.

$(0.7 \%)$, therefore, the sample consisted of 282 patients. Quality control for the Kappa parameter showed agreement higher than 0.85 for the studied variables. The prevalence of anxiety among inpatients in the clinical ward was of $33.7 \%$ (95\%CI 28.2 - 39.3).

In the descriptive analysis (Table 1), sociodemographic data revealed that mean age was of 53.1 years old (SD 15.9) and ranged from 18 to 84 years old. Most of them are white $(68.44 \%)$, male $(50.35 \%)$ and lived without a partner (50.35\%). Mean per capita income was of $\mathrm{R} \$ 435.50$ (SD $\mathrm{R} \$ 357.90)$. Most of the patients were out of work (67.37\%). Most were literate (84.40\%), however, only $25.90 \%$ had concluded elementary school. Concerning habits and costumes, there was high prevalence of smokers, high rates of alcohol use and abuse and a few patients self-declaring the practice of regular physical activities. More than one third of the patients had been hospitalized in the previous year; most of the interviewees had been previously diagnosed with some chronic pathology, and Systemic Arterial Hypertension (SAH) was the most mentioned one, followed by gastrointestinal and respiratory conditions. The matter related to the presence of a reference doctor who they go to when feeling sick obtained $65.50 \%$ of affirmative answers and, out of these, $84.86 \%$ usually attend some sort of public service. The mean time since patients have seen this professional was 7.34 years (SD 6.18 years). Days of hospitalization ranged from 2 to 85 days (mean: 10.28, SD 9.52 days). In the admission medical prescription, $11.35 \%$ of them had more than 8 classes of medication. The most prescribed one was that of painkillers (84\%). The prescription of anxiolytics and antidepressants was much less expressive (15.60 and $10.65 \%$, respectively). Most patients had been examined/ interviewed by students.

In Tables 2 and 3, the distribution of anxiety according to associated factors is observed. Concerning the sociodemographic characteristics, only gender showed a statistically significant relation. No significant results were obtained for the variables concerning habits and costumes. The number and some types of pre-existing chronic pathologies were associated with the outcome. With regard to current hospitalization and number of classes of prescribed medicines, the anxiolytic class and the estimated time of stay of the graduate student were significant.

The multivariate phase of the analysis (Table 4) revealed that the female gender in this study is associated with the anxiety of hospitalized patients. Concerning age, there is significant association, with lower prevalence among the older patients. As to the place they usually attend in terms of health care, it was observed that appointments conducted in Primary Health Care (PHC) and the Emergency Room (ER) were thos with higher prevalence ratios. Chronic diseases associated with anxiety were Diabetes Mellitus (DM), SAH and 
Table 1 - Description of the sample. University Hospital Dr. Miguel Riet Corrêa Jr., Rio Grande, Rio Grande do Sul, 2011 ( $n=282)$.

Tabela 1 - Descrição da amostra estudada. Hospital Universitário Dr. Miguel Riet Corrêa Jr., Rio Grande, Rio Grande do Sul, 2011 ( $n=282)$.

\begin{tabular}{|c|c|}
\hline Variable & $\mathrm{n}(\%)$ \\
\hline \multicolumn{2}{|l|}{ Gender } \\
\hline Female & $140(49.6)$ \\
\hline Male & $142(50.4)$ \\
\hline \multicolumn{2}{|l|}{ Color } \\
\hline White & $193(68.4)$ \\
\hline Nonwhite & $89(31.6)$ \\
\hline \multicolumn{2}{|l|}{ Religion } \\
\hline Yes & $220(78)$ \\
\hline \multicolumn{2}{|l|}{ Marital status } \\
\hline Without a partner & $142(50.4)$ \\
\hline With a partner & $140(49.6)$ \\
\hline \multicolumn{2}{|l|}{ Age } \\
\hline $18-39$ years & $63(22.4)$ \\
\hline $40-59$ years & $111(39)$ \\
\hline$\geq 60$ years & $108(38.6)$ \\
\hline \multicolumn{2}{|l|}{ Schooling } \\
\hline$\geq 8$ years & $73(25.8)$ \\
\hline \multicolumn{2}{|c|}{ Labor activity before hospitalization } \\
\hline Did not have & $36(12.8)$ \\
\hline Was retired/pensioner & $154(54.6)$ \\
\hline Yes, did work & $92(32.6)$ \\
\hline \multicolumn{2}{|c|}{ Income (reais) in quartiles (mean \pm SD) } \\
\hline 1 & $122.73 \pm 80.82$ \\
\hline 2 & $285.94 \pm 34.11$ \\
\hline 3 & $479.75 \pm 51.04$ \\
\hline 4 & $873.33 \pm 447.53$ \\
\hline \multicolumn{2}{|l|}{ Smoker } \\
\hline Yes & $98(34.7)$ \\
\hline \multicolumn{2}{|l|}{ Fageström scale } \\
\hline$\geq 6$ points & $52(53)$ \\
\hline \multicolumn{2}{|l|}{ AUDIT } \\
\hline$\geq 8$ points & $43(15.3)$ \\
\hline \multicolumn{2}{|l|}{ CAGE } \\
\hline$\geq 2$ affirmative answers & $26(9.2)$ \\
\hline \multicolumn{2}{|l|}{ Regular physical activity } \\
\hline Yes & $50(17.7)$ \\
\hline \multicolumn{2}{|c|}{ Consult with a reference doctor when necessary } \\
\hline Yes & $185(65.6)$ \\
\hline \multicolumn{2}{|c|}{ Place of appointment with this doctor } \\
\hline $\mathrm{PHC}$ & $71(38.4)$ \\
\hline Outpatient clinic FURG & $63(34)$ \\
\hline Emergency room & $15(8.1)$ \\
\hline Another public prace & $8(4.4)$ \\
\hline Private & $28(15.1)$ \\
\hline Presence of chronic patho & \\
\hline
\end{tabular}


Table 1 - Continuation.

Tabela 1 - Continuação.

\begin{tabular}{lc}
\hline Variable & $\mathrm{n}(\%)$ \\
\hline Yes & $227(80.5)$ \\
Type of chronic pathology & $96(34)$ \\
SAH & $49(17.4)$ \\
DM & $36(12.8)$ \\
HIV & $21(7.5)$ \\
Obesity & $11(3.9)$ \\
Cancer & $13(4.6)$ \\
Autoimmune disease & $56(19.9)$ \\
Heart & $65(23)$ \\
Respiratory & $13(4.6)$ \\
Thyroidopathy & $65(23)$ \\
Gastrointestinal & $7(2.5)$ \\
Psychiatric & $10(3.6)$ \\
Renal & \\
Admission in the past 12 months & $107(38.3)$ \\
Yes & \\
Days of current hospitalization & $10.28 \pm 9.52$ \\
Mean \pm SD & \\
Number of classes of prescribed medications & $226(80)$ \\
$\geq 4$ classes & \\
Class of prescribed medication & $237(84)$ \\
Painkillers & $30(10.64)$ \\
Antidepressants & $44(15.60)$ \\
Anxiolytics & \\
Presence of the student & $205(72.6)$ \\
Yes & $19(9.0)$ \\
Up to 10 min & $56(27.6)$ \\
$11-20$ min & $48(23.1)$ \\
$21-30$ min & \\
$>30$ min & \\
\hline & \\
\hline
\end{tabular}

obesity. There was a significant association with regard to the variable "estimate of the patient about the time the student stayed with him/her". The PR variation, in relation to the stratified time intervals, showed a " $U$ " pattern, that is, the association is higher in time extremes and lower in middle categories in relation to those who did not have the presence of the students.

\section{Discussion}

This study found a prevalence of anxiety of $33.7 \%$ (95\%CI $28.2-39.3)$ among inpatients in the clinical ward of a general university hospital. In literature, such prevalence is found at an intermediate rate when compared to data found in other studies. In case of a study conducted in a hospital of Minas Gerais, the proportion of $46 \%$ was found ${ }^{3}$, however, this study was developed with inpatients in several and distinct wards. A Chilean study pointed out to the prevalence of $28.9 \%$ among inpatients of internal medicine ${ }^{10}$, using another instrument to assess the prevalence of anxiety. In Brazil, a study conducted to validate the HADS scale, in 1995, obtained 
Table 2 - Distribution of anxiety according to socio demographic characteristics. Universit Hospital Dr. Miguel Riet Corrêa Jr., Rio Grande, Rio Grande do Sul, 2011 ( $n=282)$.

Tabela 2 - Distribuição da ansiedade segundo características sociodemográficas. Hospital Universitário Dr. Miguel Riet Corrêa Jr., Rio Grande, Rio Grande do Sul, 2011 ( $n=282)$.

\begin{tabular}{lccc}
\hline Variable & $\begin{array}{c}\text { Without anxiety } \\
\%(187)\end{array}$ & $\begin{array}{c}\text { With anxiety } \\
\%(95)\end{array}$ & p-value \\
\hline Gender & & & \\
Male & $80.28(114)$ & $19.72(28)$ & $0.001^{\mathrm{a}}$ \\
$\quad$ Female & $52.18(73)$ & $47.82(67)$ & \\
Color & & & \\
$\quad$ White & $65.28(126)$ & $34.72(67)$ & $0.59^{\mathrm{a}}$ \\
$\quad$ Nonwhite & $68.54(61)$ & $31.46(28)$ & \\
Religion & & & \\
$\quad$ Yes & $64.94(113)$ & $35.06(61)$ & $0.81^{\mathrm{a}}$ \\
No & $67.74(42)$ & $32.26(20)$ & \\
Marital status & & & \\
$\quad$ Yes, but not practicing & $69.57(32)$ & $30.43(14)$ & $0.64^{\mathrm{a}}$ \\
Without a partner & $67.61(96)$ & $32.39(46)$ & \\
With a partner & $65(91)$ & $35(49)$ & \\
Categorized age & & & \\
$\quad 18-39$ years & $58.73(37)$ & $41.30(26)$ & $0.06^{\mathrm{b}}$ \\
$40-59$ years & $64.55(71)$ & $35.50(39)$ & \\
$\geq 60$ years & $72.2(78)$ & $27.80(30)$ & \\
Schooling & & & \\
$\geq 8$ years of study & $68.49(50)$ & $31.51(23)$ & $0.64^{\mathrm{a}}$ \\
Work activity before hospitalization & & & \\
$\quad$ No & $63.89(23)$ & $36.11(13)$ & $0.85^{\mathrm{a}}$ \\
Retired/pensioner & $65.58(101)$ & $34.42(53)$ & \\
$\quad$ Yes & $68.48(63)$ & $31.52(29)$ & \\
Income in quartiles & & & \\
1 & $65.75(48)$ & $34.25(25)$ & $0.076^{\mathrm{a}}$ \\
2 & $58.82(40)$ & $41.18(28)$ & \\
3 & $78.08(57)$ & $21.92(16)$ & \\
4 & $61.76(42)$ & $38.24(26)$ & \\
\hline
\end{tabular}

${ }^{\mathrm{a}} \mathrm{Chi}$-square test; ${ }^{\mathrm{b}} \mathrm{Teste}$ de heterogeneidade.

${ }^{a} Q u i$ quadrado; ${ }^{\text {bHeterogeneity test. }}$

$20.5 \%^{7}$. This difference found in the studies between the levels of prevalence of anxiety is probably a reflex of the employment of different methodologies, as well as the differences between the analyzed samples.

In relation to gender, this study found higher prevalence among women, with significant association and $\mathrm{PR}=2.44$ (95\%CI 1.68 - 3.56). In previous studies conducted with inpatients, there were similar prevalence results ${ }^{7,3,10}$. The prevalence of women amongst patients with depressive or anxiety disorders was confirmed by specialized scientific literature ${ }^{18,19}$.

Schooling and income seem to be associated with anxiety. In a research conducted in the USA, with people in the community aged more than 55 years old, it was observed that anxiety inversely varied according to educational levels and socioeconomic status ${ }^{20}$. However, in this study, in a hospitalized population with similar socioeconomic conditions, schooling and income did not show any association with the outcome.

As to the age variable, this study showed significant and inverse association with anxiety. For those aged $\geq 60$ years, PR was 0.65 for anxiety in relation to the group aged between 18 and 39 years old. A population-based study conducted in Australia observed that the prevalence of anxiety had a statistically significant decline with age among women, but this pattern was not reproduced by $\mathrm{men}^{21}$. Other factors indicate that depressive and 
Table 3 - Distribution of the anxiety second characteristics studied. University Hospital Dr. Miguel Riet Corrêa Jr., Rio Grande, Rio Grande do Sul, 2011 ( $n=282$ ).

Tabela 3 - Distribuição da ansiedade segundo características estudadas. Hospital Universitário Dr. Miguel Riet Corrêa Jr., Rio Grande, Rio Grande do Sul, 2011 ( $n=282)$.

\begin{tabular}{|c|c|c|c|c|}
\hline Variable & & $\begin{array}{c}\text { Without anxiety } \\
\%(187)\end{array}$ & $\begin{array}{l}\text { With anxiety } \\
\%(95)\end{array}$ & p-alue \\
\hline \multirow[t]{4}{*}{ Categorized AUDIT } & $0-7$ points & $64.44(154)$ & $35.56(85)$ & $0.070^{\mathrm{a}}$ \\
\hline & $8-15$ points & $80.95(17)$ & $19.05(4)$ & \\
\hline & $16-19$ points & $42.86(3)$ & $57.14(4)$ & \\
\hline & $20-40$ points & $86.67(13)$ & $13.33(2)$ & \\
\hline \multirow[t]{2}{*}{ CAGE } & $\geq 2$ Affirmative answers & $69.23(18)$ & $30.77(08)$ & $0.740^{\mathrm{a}}$ \\
\hline & $<2$ Affirmative answers & $66.02(169)$ & $33.98(87)$ & \\
\hline \multirow[t]{3}{*}{ Smoker } & Yes & $68(68)$ & $32(32)$ & $0.560^{\mathrm{a}}$ \\
\hline & No & $62.24(61)$ & $37.76(37)$ & \\
\hline & Former-smoker & $69.05(58)$ & $30.95(26)$ & \\
\hline \multirow[t]{2}{*}{ Fageström scale } & $\geq 6$ points & 71.15 (37) & $28.85(15)$ & $0.390^{\mathrm{a}}$ \\
\hline & $<6$ points & $63.04(29)$ & $36.96(17)$ & \\
\hline \multirow[t]{2}{*}{ Regular physical activity } & Yes & $66(33)$ & $34(17)$ & $0.959^{\mathrm{a}}$ \\
\hline & No & $66.38(154)$ & $33.62(78)$ & \\
\hline \multirow{2}{*}{$\begin{array}{l}\text { Consult with a reference doctor when } \\
\text { necessary }\end{array}$} & Yes & $59.46(110)$ & $40.54(75)$ & $0.001^{\mathrm{a}}$ \\
\hline & No & $79.38(77)$ & $20.62(20)$ & \\
\hline \multirow[t]{5}{*}{ Place of appointment with this doctor } & Primary Care & $47.89(34)$ & $52.11(37)$ & $0.161^{\mathrm{a}}$ \\
\hline & FURG outpatient clinic & $71.43(45)$ & $28.57(18)$ & \\
\hline & Emergency room & $40(6)$ & $60(9)$ & \\
\hline & Another public service & $62.50(5)$ & $37.50(3)$ & \\
\hline & Private & $71.43(20)$ & $28.57(8)$ & \\
\hline \multirow[t]{3}{*}{ Number of previous chronic pathologies } & 1 (up to 2 pathologies) & $73.06(160)$ & $26.94(59)$ & $0.001^{c}$ \\
\hline & 2 (3 pathologies) & $55(22)$ & $45(18)$ & \\
\hline & 3 (4 pathologies) & $21.74(5)$ & $78.26(18)$ & \\
\hline \multicolumn{5}{|l|}{ Type of chronic pathology } \\
\hline \multirow[t]{2}{*}{$\mathrm{DM}$} & Yes & $46.94(23)$ & $53.06(26)$ & $0.002^{\mathrm{a}}$ \\
\hline & No & $70.39(164)$ & $29.61(69)$ & \\
\hline \multirow[t]{2}{*}{$\mathrm{SAH}$} & Yes & $52.08(50)$ & $47.92(46)$ & $0.001^{\mathrm{a}}$ \\
\hline & No & $73.66(137)$ & $26.34(49)$ & \\
\hline \multirow[t]{2}{*}{ HIV } & Yes & $77.78(28)$ & $22.22(8)$ & $0.119^{\mathrm{a}}$ \\
\hline & No & $64.63(159)$ & $35.37(87)$ & \\
\hline \multirow[t]{2}{*}{ Obesity } & Yes & $28.57(6)$ & $71.43(15)$ & $0.001^{\mathrm{a}}$ \\
\hline & No & $69.35(181)$ & $30.65(80)$ & \\
\hline \multirow[t]{2}{*}{ Cardiac } & Yes & $51.79(29)$ & $48.21(27)$ & $0.001^{\mathrm{a}}$ \\
\hline & No & $69.91(158)$ & $30.09(68)$ & \\
\hline \multirow[t]{2}{*}{ Psychiatric } & Yes & $42.86(3)$ & $57.14(4)$ & $0.180^{\mathrm{a}}$ \\
\hline & No & $66.91(184)$ & 33.09 (91) & \\
\hline \multirow[t]{2}{*}{ Hospitalization in the past 12 months } & Yes & $58.88(63)$ & $41.12(44)$ & $0.040^{\mathrm{a}}$ \\
\hline & No & $70.69(123)$ & $29.31(51)$ & \\
\hline Days of current hospitalization & Mean (SD) & $10.2(9.10)$ & $10.4(10.35)$ & $0.830^{\mathrm{b}}$ \\
\hline \multirow{4}{*}{$\begin{array}{l}\text { Number of classes of medicines prescribed } \\
\text { during hospitalization }\end{array}$} & Up to 3 classes & $75(36)$ & $25(12)$ & $0.010^{c}$ \\
\hline & $4-5$ classes & $70.18(80)$ & $29.82(34)$ & \\
\hline & $6-7$ classes & $66.25(53)$ & $33.75(27)$ & \\
\hline & $\geq 8$ classes & $43.75(14)$ & $56.25(18)$ & \\
\hline \multirow[t]{3}{*}{ Type of prescribed medication } & Anxiolytics & $52.27(23)$ & $47.73(21)$ & $0.032^{\mathrm{a}}$ \\
\hline & Painkillers & $67.5(160)$ & $32.5(77)$ & $0.320^{\mathrm{a}}$ \\
\hline & Antidepressants & $63.3(19)$ & $36.7(11)$ & $0.710^{\mathrm{a}}$ \\
\hline \multirow{2}{*}{ Presence of the student } & Yes & $68(136)$ & $32 \%(64)$ & $0.490^{\mathrm{a}}$ \\
\hline & No & $63.64(49)$ & $36.36 \%(28)$ & \\
\hline \multirow{4}{*}{$\begin{array}{l}\text { Estimate of the patient about the time the } \\
\text { student remained with him/her }\end{array}$} & $5-10 \min$ & $44.44(8)$ & $55.56 \%(10)$ & $0.001^{\mathrm{a}}$ \\
\hline & $11-20 \mathrm{~min}$ & $80(64)$ & $20 \%(16)$ & \\
\hline & $21-30 \mathrm{~min}$ & $72.73(40)$ & $27.27 \%(15)$ & \\
\hline & $>30 \mathrm{~min}$ & $50(23)$ & $50 \%(23)$ & \\
\hline
\end{tabular}

${ }^{\mathrm{a}} \mathrm{Chi}$-square test; ${ }^{\mathrm{b}} \mathrm{Heterogeneity} \mathrm{test;}{ }^{\mathrm{C}}$ Linear trend test.

${ }^{\mathrm{a}}$ Qui-quadrado; ${ }^{\mathrm{b}}$ Teste de heterogeneidade; 'Teste de tendência linear. 
Tabela 4 - Razões de prevalência e IC95\% ajustadas para ansiedade e fatores associados (modelo final), em pacientes internados na enfermaria de clínica médica. Hospital Universitário Dr. Miguel Riet Corrêa Jr., Rio Grande, Rio Grande do Sul, $2011(n=281)$.

Table 4 - Adjusted prevalence ratios and 95\% Cl for anxiety and associated factors (final model), in patients hospitalized in the clinical ward. University Hospital Dr. Miguel Riet Corrêa Jr., Rio Grande, Rio Grande do Sul, 2011 ( $n=281)$.

\begin{tabular}{|c|c|c|c|c|}
\hline Variable & & PR & $95 \% \mathrm{Cl}$ & $p$-value \\
\hline \multicolumn{5}{|l|}{ First level of analysis } \\
\hline \multirow[t]{2}{*}{ Gender } & Male & 1 & & \\
\hline & Female & 2.44 & $1.68-3.56$ & $0.0001^{\mathrm{a}}$ \\
\hline \multirow[t]{3}{*}{ Age } & $18-39$ & 1 & & \\
\hline & $40-59$ & 0.84 & $0.56-1.21$ & $0.04^{c}$ \\
\hline & 60 ou + & 0.65 & $0.43-0.99$ & \\
\hline \multirow[t]{2}{*}{ Schooling $\geq 8$ years } & No & 1 & & \\
\hline & Yes & 0.72 & $0.49-1.06$ & $0.1^{\mathrm{a}}$ \\
\hline \multicolumn{5}{|l|}{ Second level of analysis } \\
\hline \multirow[t]{4}{*}{ AUDIT } & $0-7$ points & 1 & & $0.16^{\mathrm{b}}$ \\
\hline & $8-15$ points & 0.74 & $0.35-1.55$ & \\
\hline & 16-19 points & 2.14 & $0.90-5.08$ & \\
\hline & $20-40$ points & 0.54 & $0.16-1.81$ & \\
\hline \multicolumn{5}{|l|}{ Third level of analysis } \\
\hline \multirow[t]{6}{*}{ Place of appointment } & Não consulta & 1 & & $0.0008^{b}$ \\
\hline & Atenção primária & 2.37 & $1.53-3.67$ & \\
\hline & Ambulatório da FURG & 1.24 & $0.74-2.07$ & \\
\hline & Pronto-socorro & 2.34 & $1.20-4.26$ & \\
\hline & Outro local público & 1.36 & $0.53-3.47$ & \\
\hline & Privado & 1.37 & $0.67-2.78$ & \\
\hline \multicolumn{5}{|l|}{ Forth level of analysis } \\
\hline \multicolumn{5}{|l|}{ Pre-existing chronic diseases: } \\
\hline DM & & 1.43 & $1.01-2.02$ & $0.04^{\mathrm{a}}$ \\
\hline SAH & & 1.57 & $1.12-2.18$ & $0.007^{a}$ \\
\hline Obesity & & 1.43 & $1.06-1.91$ & $0.016^{\mathrm{a}}$ \\
\hline \multirow{5}{*}{$\begin{array}{l}\text { Estimate of the patient about the time } \\
\text { the student remained with him/her }\end{array}$} & None & 1 & & \\
\hline & Up to $10 \mathrm{~min}$ & 1.34 & $0.81-2.22$ & $0.007^{b}$ \\
\hline & $11-20 \mathrm{~min}$ & 0.61 & $0.38-1.00$ & \\
\hline & $21-30 \mathrm{~min}$ & 0.76 & $0.47-1.25$ & \\
\hline & $>30 \min$ & 1.36 & $0.95-1.93$ & \\
\hline
\end{tabular}

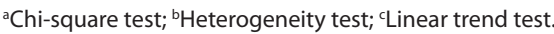

${ }^{a}$ Qui-quadrado; ${ }^{b}$ Teste de heterogeneidade; ${ }^{\top}$ Teste de tendência linear.

anxiety disorders are very prevalent among the elderly ${ }^{22}$. Due to such divergences in the prevalence findings and because of the lack of consistence concerning the existence or not of an association between older age and anxiety among inpatients, and also because of the particular functioning of this age group, we believe the creation of a proper and reliable scale is useful to measure the anxiety among the elderly, especially among people who are hospitalized.
From the point of view of use of medical assistance, this study revealed an association between the place where the patient usually goes to when feeling a health issue with anxiety. The ER and PHC were the places with higher prevalence ratios ( $P R>2.3$ ) in relation to those interviewees who usually do not see a doctor. It is known that the presence of anxiety in a patient hospitalized in a general hospital can be a manifestation of a pre-existing psychiatric disorder in which anxiety is 
prevalent as a symptom ${ }^{23}$. The patient who frequently seeks assistance in the ER is usually has severe acute or reacute conditions (highly anxiogenic situations) and, also, who could present with tendencies of immediatism and lack of a connection with a specific doctor. On the other hand, epidemiological studies demonstrate the high prevalence of mental disorders in patients assisted in primary care ${ }^{24,25}$. These facts can be related to the finding in this study. It is not necessarily just the place of usual care that increases the anxiety of the inpatient, considering that many patients already have previous risk factors to develop anxiety at the time of hospital admission.

Several organic illnesses can present anxiety as a symptom ${ }^{23}$. In our study, after adjustment with other confusion factors, interviewees who had $\mathrm{SAH}$, obesity and $\mathrm{DM}$ as pre-existing chronic conditions were significantly more anxious. These findings corroborate the researched literature. Concerning SAH, a German study obtained statistically significant difference between hypertensive and control individual ${ }^{26}$. Other studies also demonstrate the association between SAH and anxiety ${ }^{27,28}$. Concerning obesity, there seems to be a directly proportional relation between the presence of depression and anxiety symptoms with Body Mass Index (BMI ${ }^{29}$. A study involving patients with severe obesity pointed out to the high incidence of anxiety and depression symptoms in these patients $^{30}$. In relation to DM, a population study in Germany found the association of diabetes with anxiety disorders ${ }^{31}$.

Other clinical conditions are associated with higher prevalence of anxiety. It is known that heart conditions are associated with this disease ${ }^{23}$. In our study, in the stage of bivariate analysis, there was significant association of heart disease with anxiety; however, such association was lost after the adjustment. Anxiety disorders are also prevalent among patients infected by HIV, especially in diagnosis situations, new treatments and acute disease ${ }^{32}$. However, in this study, this disease did not show significant association with the outcome. This non-association may have occurred due to the reduced number of patients with heart disease and with diagnosis of HIV found in this study.

The high rate of patients with prescribed painkillers (84\%) may have been related to the fact that anxiety decreases the pain threshold, which ends up leading to the prescription of fewer painkillers ${ }^{23}$, however, in this study there was no significant association between these two variables. The same occurred with the class of antidepressants and anxiolytics. In the bivariate analysis, anxiolytics had significant p-value, however, this association was lost after the adjustment.

Meta-analyses about physical exercise and mental health concluded that physical activities are efficient to reduce anxiety ${ }^{33,34}$. In our study, the association between selfdeclared regular physical exercise and anxiety has not been shown. We emphasize that the study was carried out with hospitalized patients, however, away from their habitat and daily activities, which may interfere with the results.

Epidemiological and clinical studies have demonstrated a positive and significant association between smoking and anxiety disorders ${ }^{35,36}$. Smoking has a complex interference on mood, and abstinence transitorily worsens mood, anxiety and cognition ${ }^{37}$. Even though the reviewed literature indicates strong evidence of association between smoking and anxiety disorders, this was not observed among the participants in this study. In this research, the association was not confirmed even patients with Fageström score $\geq 6$ points (with possibility to have abstinence crisis).

It is known that anxiety or depressive disorders are the most commonly psychiatric comorbities associated with alcoholic patients $^{38}$, however, in this study, alcohol use and abuse did not show significant association with the outcome. 
This study showed the association between the anxietiy of inpatients in a clinical ward of a university hospital with the variable estimates of the patient about the time the student stayed with him/her. An interesting fact was the variation of $P R$ in relation to stratified time intervals that showed a "U" pattern, demonstrating that the association is higher in time extremes and lower in middle categories with relation to the base category. This finding can be related to several factors. For instance, it is possible that, depending on the time the student stays in touch with the patient anxiety increases and/or decreases. However, it is plausible that anxious patients can, at the same time, depending on the way the student reacts to the psychosocial complaints, "repel" and/or "restrain" the students even more. Therefore, this finding should be made clearer by other studies; if the association is confirmed, the question that comes up is related to the ideal time for the student to stay with the hospitalized patient.

Concerning the methodological limitations of the study, we can mention that it is a cross-sectional study, therefore, the possibility of reverse causality is inevitable. We conducted the study in a school hospital, so, the results cannot be extrapolated to other general hospitals in Brazil. The reduced sample size may have decreased the statistical power for some associations.

\section{Conclusions}

This study identified high prevalence of anxiety among hospitalized patients in the clinical ward of a university hospital. The conclusion was that, by controlling the effect of variables that generate confusion, there is a significant association between the anxiety of these hospitalized patients with gender variables (higher among women), age (higher among young people), usual place of medical care (higher in PHC and ER), some chronic pre-existing diseases (higher among diabetic, hypertensive and obese patients) and the estimate of the patient about the time the student stayed with him.

This profile will enable the assistant doctor to identify the patients who are most likely to suffer with anxiety during hospital stay and, therefore, recognize the individuals with anxiety early so that the proper therapy can be administered.

The performance of more studies is suggested to analyze the anxiety in this population, as well as other designs and instruments, with more participants to better elucidate the factors associated with the outcome.

Due to the high prevalence of anxiety, the study points out to the real need to make an approach more addressed to mental health in the scenario of hospital care available.

\section{References}

1. Caponi R. La angustia según Freud, Klein y Bion. Rev Chil Neuro-Piquiat 1994; 32: 151-4.

2. Dalgalarrondo P. Psicopatologia e semiologia dos transtornos mentais. Porto Alegre: Artmed; 2000.

3. Delfini ABL, Roque AP, Peres RS. Sintomatologia ansiosa e depressiva em adultos hospitalizados: rastreamento em enfermaria clínica. Gerais: Revista Interinstitucional de Psicologia 2009; 2(1): 12-22.

4. Lecrubier Y. The burden of depresion and anxiety in general medicine. J Clin Psychiatry 2001; 62(Suppl 8): 4-9.
5. Katon W, Sullivan M, Walker E. Medical symptoms without identified pathology: relationship to psychiatric disorders, childhood and adult trauma and personality traits. Ann Intern Med. 2001; 134(9 Pt 2): 917-25.

6. Kessler RC, Greenberg PE, Mickelson KD, Meneades LM, Wang PS. The effects of chronic medical conditions on work loss and work cutback. J Occup Environ Med 2001; 43(3): 218-25.

7. Botega NJ, Bio MR, Zomignani MA, Garcia C Jr, Pereira WA. Transtornos de humor em enfermaria de clínica médica e validação de escala de medida (HAD) de ansiedade e depressão. Rev Saude Publica 1995; 29(5): 355-63. 
8. Castro MMC, Quarantini L, Batista-Neves S, Kraychete DC Daltro C, Miranda-Scippa A. Validade da escala hospitalar de ansiedade e depressão em pacientes com dor crônica. Rev Bras Anestesiol 2006; 56(5): 470-7.

9. Marcolino JA, Suzuki FM, Alli LA, Gozzani JL, Mathias LA. Medida da ansiedade e da depressão em pacientes no pré-operatório. Estudo comparativo. Rev Bras Anestesiol 2007; 57(2): 157-66.

10. Hernández G, Orellana G, Kimelman M, Nuñez C, Ibáñez C. Trastornos de ansiedad en pacientes hospitalizados en Medicina Interna. Rev Med Chil 2005; 133(8): 895-902.

11. Castells MA, Furlanetto LM. Validity of the CAGE questionnaire for screening alcohol-dependent inpatients on hospital wards. Rev Bras Psiquiatr 2005; 27(1): 54-7.

12. Méndez EB. Uma Versão Brasileira do AUDIT (Alcohol Use Disorders Identification Test) [dissertação]. Pelotas: Faculdade de Medicina, Universidade Federal de Pelotas; 1999.

13. Ewing JA. Detecting alcoholism. The CAGE questionnaire. JAMA 1984; 252(14): 1905-7.

14. Barbor TE, La Fuente JR, Saunders J, Grant M. AUDIT- The alcohol use disorders identification test: guidelines for use in primary care. WHO (PSA/92). 1992; 4: 1-29.

15. Halty LS, Hüttner MD, Oliveira Netto IC, Santos VA, Martins G. Análise da utilização do Questionário de Tolerância de Fagerström (QTF) como instrumento de medida da dependência nicotínica. J Pneumol 2002; 28(4): 180-6.

16. Zigmond AS, Snaith RP. The hospital anxiety and depression scale. Acta Psychiatr Scand 1983, 67(6): 361-70.

17. Victora CG, Huttly SR, Fuchs SC, Olinto MTA. The role of conceptual frameworks in epidemiological analysis: a hierarchical approach. Int J Epidemiol. 1997; 26(1): 224-7.

18. Moreno DH, Dias RS, Kerr-Corrêa F, Moreno RA. Transtornos do humor. In: Cordás TA, Salzano FT. (orgs) Saúde mental da mulher. São Paulo: Atheneu; 2004. p. 105-40.

19. Nardi AE. Transtornos de ansiedade. In: Cordás TA, Salzano FT. (orgs.). Saúde mental da mulher. São Paulo: Atheneu; 2004. p. 141-59.

20. Himmelfarb S, Murrell SA. The prevalence and correlates of anxiety symptoms in older adults. J Psychol 1984; 116(2d Half): 159-67.

21. Henderson AS, Jorm AF, Korten AE, Jacomb P, Christensen $\mathrm{H}$, Rodgers B. Symptoms of depression and anxiety during adult life: evidence for a decline in prevalence with age. Psychol Med. 1998; 28(6): 1321-8.

22. Almeida OP. Elderly treated in mental health emergency rooms: demographic and clinic characteristics. Rev Bras Psiquiatr 1999; 21(1): 12-8.
23. Botega NJ, editor. Prática psiquiátrica no hospital geral: interconsulta e emergência. 2a ed. Porto Alegre: Artmed; 2006.

24. Maragno L, Goldbaum M, Gianini RJ, Novaes HM, César CL. Prevalence of common mental disorders in a population covered by the Family Health Program (QUALIS) in São Paulo, Brazil. Cad Saude Publica 2006; 22(8): 1639-48.

25. Bandeira M, Freitas LC, Carvalho Filho JGT. Assessment of common mental disorders in the Programa de Saúde da Família users. J Bras Psiquiatr 2007; 56(1): 41-7.

26. van der Ploeg HM, van Buuren ET, van Brummelen P. The role of anger in hypertensive. Psychother Psychosom 1985; 43(4): 186-93.

27. Coelho R, Hughes AM, Fonseca AF, Bond MR. Essential Hypertension: The relationship of Psychological Factors to the severity of hypertension. J Psychosom Res 1989; 33(2): 187-96.

28. Moum T, Naess S, Sørensen T, Tambs K, Holmen J. Hypertension labelling, life events and psychological well-being. Psychol Med 1990; 20: 635-46.

29. Segal A, Cardeal, MV, Cordas, TK. Aspectos psicossocias e psiquiátricos da obesidade. ABESO - Órgão Informativo da Associação Brasileira para o Estudo da Obesidade [periódico na Internet] 2003 [acessado 2011 jun 26];12:[cerca de 3 p.]. Disponível em: <http://www.hcnet.usp.br/ipq/revista/ vol29/n2/81.html>

30. Matos MIR, Zanella MT. Alterações do comportamento alimentar, ansiedade, depressão e imagem corporal em pacientes com obesidade grau III. ABESO - Órgão Informativo da Associação Brasileira para o Estudo da Obesidade [periódico na Internet] 2003 [acessado 2011 jun 26]. Disponível em: <http://www.abeso.org.br/revista/ revista9/alteracoes.htm>

31. Kruse J, Schmitz N, Thefeld W; German National Health Interview and Examination Survey. On the association between diabetes and mental disorders in a community sample: results from the German National Health Inteview and Examination Survey. Diabetes Care 2003; 26: 1841-6.

32. Elliott A. Anxiety and HIV infection. STEP Perspect 1998; 98(1): 11-4.

33. Petruzzello SJ, Landers DM, Hatfield BD, Kubitz KA, Salazar W. A meta-analysis on the anxiety-reducing effects of acute and chronic exercise. Outcomes and mechanisms. Sports Med 1991; 11(3): 143-82.

34. Werneck FZ, Bara Filho MG, Ribeiro LCS. Efeitos do exercício físico sobre os estados do humor: uma revisão. Rev Bras Psicol Esp Exercício 2006; 0: 22-54.

35. Isensee B, Wittchen HU, Stein MB, Höfler M, Lieb R. Smoking increases the risk of panic: findings from a prospective community study. Arch Gen Psychiatry 2003; 60(7): 692-700. 
36. Degenhardt L, Hall W. The relationship between tobacco use, substance-use, disorders and mental health: results from the National Survey of Mental Health and Well-being. Nicotine Tob Res 2001; 3(3): 225-34.

37. Malbergier A, Oliveira Jr HP. Tobacco dependence and psychiatric comorbity. Rev Psiq Clin 2005; 32(5): 276-82.
38. Alves H, Kessler F, Ratto LR. Comorbidade: Uso de álcool e outros transtornos psiquiátricos. Rev Bras Psiquiat 2004; 26 Suppl 1: S51-3.

Received on: 11/11/11

Final version presented on: 03/27/13

Accepted on: 05/29/13 